\title{
Detection of earnings management by different models
}

\author{
Yuriy Bilan ${ }^{1}$, and Veronika Jurickova ${ }^{2, *}$ \\ ${ }^{1}$ Sumy State University, Ukraine \\ ${ }^{2}$ University of Zilina, The Faculty of Operation and Economics of Transport and Communications, \\ Department of Economics, Univerzitna 1, 01026 Zilina, Slovakia
}

\begin{abstract}
.
Research background: Earnings management means the usage of gaps in the legislative frameworks of individual countries and their accounting systems in the global world. Businesses thus adjust profits and revenues to the form that is desirable and desired for them. However, there is a very thin line between fraud and earnings management. By adjusting their financial statements, companies seek to impress potential investors and influence their own market position.

Purpose of the article: The main goal of the article is to describe the possibilities and methods of detection of earnings management in companies in aspects of globalization. The article contains a brief overview of theoretical knowledge and definitions about earnings management. The contribution of the article lies in the application of the selected method to a specific company and based on the outputs of the model to determine whether the company is using earnings management.

Methods: The scientific method of analysis was used in the article, on the basis of which the obtained information was necessary for further calculations. A calculation based on the Beneish model was used to determine the use of earnings management.

Findings \& Value added: The output of the article is the application of the Beneish model in the detection of earnings management in a selected company. In the calculation process, pre-established theoretical knowledge on the issue and the numerical characteristics of the selected company were used. Finally, the application of earnings management in the company can be ruled out.
\end{abstract}

Keywords: Earnings management; the Beneish model; the CFEBT model; the Q-DMFC model.

JEL Classification: $K 20, M 22, M 41$

\footnotetext{
*Corresponding author: veronika.galgankova@,fpedas.uniza.sk
} 


\section{Introduction}

Earnings management belongs to the range of financial fraud or financial crime, which result in the recognition of profits in an incomplete or untrue manner. Earnings management should be carried out with an awareness of the moral responsibility of each company to its customers, stakeholders [1]. Earings management is carried out using practices such as Income Smoothing, and Big Bath Charges. In the second area in terms of Earnings Quality (profit quality management), techniques such as aggressive accounting, Window Dressing (a strategy to improve financial reports), and last but not least, the so-called off-balance-sheet financing [2].

The first of the definitions related to earnings management is the definition by Degeorg, Patel, and Zeckhauserem (1999): "Earnings management is a strategic use of managerial judgment in influencing profit values reported by external users shift between periods "[3].

The second possible definition describes earnings management as a deliberate intervention in the external financial reporting process to obtain a private contribution (as opposed to facilitating the neutrality of the process) [4].

Another possible view of earnings management, which is captured in the following definition, is given by Healy, and Wahlen either deceiving certain stakeholders with regard to the company 's economic performance or influencing contractual outputs that depend on reported accounting figures [5].

The last of these definitions refer to a broader framework of financial fraud, namely fraud in financial (accounting) statements: "Fraud in financial statements is an intentional attempt by companies to deceive or deceive the user published financial statements, in particular by investors, and creditors, by preparing, and distributing materially misstated financial statements "[6].

Mulford and Comiskey define: "Earnings management is the active manipulation of revenues to a predetermined amount, usually determined by management or analysts on the basis of a forecast, or an amount that goes smoothly in line with sustainable revenues." [7].

Looking at all the above definitions, one can find common features, as well as some differences in the view of earnings management. All definitions agree that managers themselves intentionally make adjustments to external statements for a specific purpose. A slightly different concept can be determined on the basis of Degeorge, Patel, and Zeckhauser, as they emphasize that this is a strategic activity or discretion and that there is a shift in value between periods. This approach is also reflected in their further breakdown of earnings management into:

- direct earnings management;

- incorrect reporting of results.

Direct earnings management means real strategic activities in the form of decisions on financing, sales, costs, and investment timing. The second form means any accounting records that have already been prepared.

A similar division of earnings management is based on Burgstahler and Eames who divide it into:

- "Business management";

- "Reporting management".

The first definition is understood as the activity related to changes in the actual operation of the company, which is carried out by means of real shares, and subsequently affects the actual cash flows in the operation of the company. The second concept again only concerns accounting changes, which are mostly made through accrual accounts [8].

Earnings management combines the requirements of top management in the field of profit and the actual manipulation of the financial statements, and accounting processes [9]. Creative accounting is therefore essentially an integral part of earnings management. In a 
society where earnings management is practiced, the accountant usually automatically expects to use creative techniques in bookkeeping. Earnings management can use all related techniques with adjustment of the economic result [10]. For this reason, it includes both techniques off-balance sheet, and window dressing. One of the most common methods of profit adjustment is income smoothing a big bath.

The income smoothing method "smoothes" the profit so that it does not fall, ideally so that it has a slight growing trend. Revenues from successful years are carried over to the period when the company is in operation worse, thus eliminating losses.

The big bath method is used especially when the enterprise first shows a loss but assumes a profit in the future. In this case, the company does not try to reduce its loss, but on the contrary, it will intentionally deepen it, and in the next period, it will artificially increase its profit. This leap can work in favor of new managers, who then act more capable than their predecessors.

Income smoothing is used in most cases for a long time, while the big bath is short-term technology, emphasizing the change in the company's situation.

Mulford also states how the most frequent are the companies using earnings management techniques if they seek income smoothing:

- minor losses are rare,

- small profits are quite common,

- small declines in profit are unusual,

- small profit increases are very common,

- the expected profits / financial indicators are almost always accurately met, or slightly exceeded,

- gains that are slightly below expectations are virtually non-existent [11].

\section{Methods}

Usage of earnings management usually wants to be invisible, to be undetected, and also it is difficult to detect it from the firms' financial statements. Appropriate values of financial indicators and financial health are the basis of a company's competitiveness [12]. It is currently possible to use several software, methods or models to increase the explanatory power of financial statements and to detect earnings management or to predict business bankruptcy [13]. There are some methods for detecting creative accounting, and fraud, for example:

- Identification by legal activities.

- Identification and negotiation using ethics, and responsibility - a company may be called upon to respond to certain offenses committed in its interests or for the benefit of its managers and employees.

- Identification and negotiation through computer applications, and software.

- Strategic fraud detection models - the models focus on formulation. The description of strategic fraud shows how the use of information systems, and technology will provide an effective way to detect fraud [14].

- Identification, and measurement using mathematically-statistically oriented models - in this group we can include, for example, the Beneish model [15].

The authors Brazel, Jones, and Zimbelman were involved in evaluating the possible presence of fraud in addition to the typical "Red Flags", they also dealt with publicly available non-financial indicators, and their relationship with the operation, and financial results of the company.

We can sort indicators according to them:

- the number of retail outlets, and the size of the warehouse,

- increase or decrease in the number of employees or customers, 
- customer satisfaction, which is significantly linked to the company's future cash flows [16].

The main advantage of such non - financial indicators is their difficult manipulation, and ease of verification (number of employees, number of individual branches, number of acquisitions, etc.) compared to other financial indicators. Of course, these can also be affected indicators. But the big plus is that some of these indicators are produced independently of the company's intervention (for example, the already mentioned customer satisfaction) [17].

The Healy model was one of the first models. This model defines estimated discretionary accruals in a period as total accruals scaled by lagged total assets. This implies that nondiscretionary accruals are expected to be zero.

$$
E D A C_{i t}=\frac{T A_{i t}}{A_{i t-1}}
$$

Where: $\mathrm{EDAC}_{\mathrm{it}}=$ estimated discretionary accruals for firm I in year $\mathrm{t}$; $\mathrm{i}=$ the firm; $\mathrm{TA}_{\mathrm{it}}=$ total accruals in year $\mathrm{t}$ for forim $\mathrm{I}, \mathrm{A}_{\mathrm{it}-\mathrm{l}}=$ total assets in year $\mathrm{t}-1$ fomm firm $\mathrm{i}$.

This is one of the simplest models. It is expected that it contains high measurement error since it does not take into account the normal operations that would require some level of accruals [18].

The DeAngelo model consists of the opinion that non-discretionary accruals follow a random walk, and uses the change in the aggregate accruals from year t- 1 to year $t$ to represent the discretionary component.

$$
E D A C_{i t}=\frac{T A_{i t}-T A_{i t-1}}{A_{i t-1}}
$$

Where: $\mathrm{EDAC}_{\mathrm{it}}=$ estimated discretionary accruals for firm I in year $\mathrm{t}$; $\mathrm{i}=$ the firm; $\mathrm{TA}_{\mathrm{it}}=$ total accruals in year $\mathrm{t}$ for forim $\mathrm{i} ; \mathrm{A}_{\mathrm{it}-1}=$ total assets in year $\mathrm{t}-1$ fomm firm $\mathrm{i}$.

The source of measurement error in this model comes from omitted variables affecting accruals in the current year. In comparission to the Healy model, the DeAngelo model should contain less measurement error [19].

The Beneish model was developed in 1999 by Professor Messod D. Beneish. It consists of eight indices that capture discrepancies in financial statements that may arise from profit manipulation or other fraudulent activities [20]. Current data in the financial statements form the basis for the calculation of indices, which generate an overall M-score, characterizing the degree of possible manipulation or fraudulent activities such as concealment or fraud [21].

Beneish also determined that if the resulting value of the model is greater than -2.22 , then there is a higher probability of manipulation in the financial statements. To understand which numbers are greater than -2.22 , it is necessary to realize that we are moving in negative numbers, so the larger is, for example, -2.21 , and the smaller is -2.23 . The table below shows the variables of the Beneish model:

Table 1. Beneish model's variables

\begin{tabular}{|l|l|}
\hline 1. & DSRI - Day's sales in receivable index \\
\hline 2. & GMI - Gross margin index \\
\hline 3. & AQI - Asset quality index \\
\hline 4. & SGI - Sales growth index \\
\hline 5. & DEPI - Depreciation index \\
\hline
\end{tabular}




\begin{tabular}{|l|l|}
\hline 6. & SGAI - Sales, and general, and administrative expenses index \\
\hline 7. & TATA- Total accruals to total assets \\
\hline 8. & LVGI - Leverage index \\
\hline
\end{tabular}

$$
\begin{gathered}
\mathrm{M}=-4,84+0,92 * \mathrm{DSRI}+0,528 * \mathrm{GMI}+0,404 * \mathrm{AQI}+0,892 * \mathrm{SGI}+0,115 * \mathrm{DEPI} \\
0,172 * \mathrm{SGAI}+4,679 * \mathrm{TATA}-0,327 * \mathrm{LVGI}
\end{gathered}
$$

The CFEBT model is based on warning signals from accounting. For example, there is an unusual increase in turnover, an unusual margin, or a constantly recurring mismatch between the increase in cash flow, and the economic result. All this in comparison with other comparable subjects in the industry [20]. The CFEBT model showed comparable results of manipulation of financial statements, which are prepared in accordance with Czech accounting principles. The determination of the model was based on the hypothesis, which held the view that there is a close relationship between accounting economic results and the change in cash flow over a period of five years.

The Q-DMFC model is a fast balance detection model. This model is based on environmental accounting. It is based on four balances, based on the material, energy, and financial metabolism of the company. The possibility of error detection, creativity, and fraud are aimed mainly at by-products of the gray economy, which result in tax evasion. The model also focuses on the possible identification of theft of products or materials [22].

\section{Results}

In the following chapter, the Beneish model was applied in a selected company, which deals with the processing, and production of food products. The Beneish model was used to detect fraud in the company's financial statements.

Table 2. Values of financial variables of the company

\begin{tabular}{|c|c|c|c|}
\hline $\begin{array}{c}\text { Financial Statement } \\
\text { Inputs }\end{array}$ & \multicolumn{3}{|c|}{ Company XYZ, s.r.o. } \\
\hline & 2018 & 2019 & Acceptable Input \\
\hline Acc. Receivable Net & 616671 & 714046 & $>0$ \\
\hline Current Assets & 718784 & 860742 & $>0$ \\
\hline Current Liabilities & 562682 & 636532 & $>0$ \\
\hline Total Assets & 1809154 & 1984926 & $>0$ \\
\hline PPE Net & 1084707 & 1120716 & $>0$ \\
\hline Long Term Debt & 315117 & 292940 & $>0$ \\
\hline Sales (Net) & 1717084 & 1847912 & $>0$ \\
\hline Depreciation Expense & 218669 & 234644 & $>0$ \\
\hline Cost of Goods Sold & 1403972 & 1329988 & $>0$ \\
\hline SGA Expense & 759508 & 979596 & Any number \\
\hline Net Income & 357750 & 104908 & \\
\hline
\end{tabular}


The values of the individual variables were then entered into the appropriate formula to determine the earnings management in the company. The following table shows the partial calculations of the individual parts of the formula [23].

Table 3. Values of individual variables of the Beneish model

\begin{tabular}{|c|c|c|}
\hline Analysis & Variable & Assessment \\
\hline Day Sales in Receivable Index & 1.076 & Assess revenue recognition \\
\hline Gross Margin Index & 0.651 & Neutral \\
\hline Asset Quality Index & 0.558 & Neutral \\
\hline Sales Growth Index & 1.076 & Neutral \\
\hline Depreciation Index & 0.969 & Neutral \\
\hline SG\&A Index & 1.198 & Increasing expenses \\
\hline Accruals to Total Assets & 0.053 & Assess changes in working capital \\
\hline Leverage Index & 0.965 & Neutral \\
\hline M-Score & $-2,484$ & No manipulation \\
\hline
\end{tabular}

The Beneish model was used to determine whether the company was manipulating its financial statements. Based on theoretical knowledge, we know that if the value of the Beneish model is higher than -2.21 , there is a probability of manipulation of the company's financial statements. In our case, the value of the Beneish model reached $-2,484$, which means that the company does not manipulate its accounting.

\section{Discussion and conclusions}

The issue of earnings management diagnostics is a relatively often researched a problem in published or unpublished research articles. Despite a large number of articles is not a uniform view of the best testing methods, and whether it is possible at all demonstrate earnings management by external testing.

The article deals with specific methods of fraud detection, which are summarized in the Heavy model, and the DeAngelo model, which are among the oldest models of earnings management detection in the company. The Beneish model consists of eight variables [24]. If the output of the model is higher than the value of -2.21 , the company has fraud with the financial statements. The relevant model was also applied to a specific company, with the final value of the model being -2.484. Based on the outputs, it is possible to conclude that the company does not manipulate the statements. The least well-known CFEBT model, which puts reported gains in the medium term, is very interesting. The last described model is the Q-DMFC model, another possibility of selection is the use of the Red Flags method. Among the means of detecting fraud properly includes a properly implemented internal control system enterprise. In conclusion to the issue of studies and research diagnostics on the presence of earnings management it can be said that although this is an issue with a relatively large number of articles and studies, there is no clear agreement on best testing methods.

The paper is an output of the science project VEGA: 1/0121/20: Research of transfer pricing system as a tool to measure the performance of national and multinational companies in the context of earnings management in conditions of the Slovak republic and V4 countries. 


\section{References}

1. Kliestik, T., Misankova, M., Valaskova, K., Svabova, L. (2018). Bankruptcy prevention: new effort to reflect on legal and social changes. Science and Engineering Ethics, 24(2), 791-803.

2. Beyer, A., Guttman, I., Marinovic, I. (2019). Earnings Management and Earnings Quality: Theory and Evidence. Accouting Review, 94(4), 77-101.

3. Degeorge, F., Patel, J., Zeckhauser, R. (1999). Earnings Management to Exceed Thresholds. Journal of Business, 72(1), 1-33.

4. Khuong, N. V., Liem, N. T., Minh, M. T. H. (2020). Earnings management and cash holdings: Evidence from energy firms in Vietnam. Journal of International Studies, 13(1), 247-261.

5. Dechow, P. M., Skinner, D. J. (2000). Earnings Management: Reconciling the Views of Accounting Academics, Practitioners, and Regulators. Retrieved from: http://papers.ssrn.com/sol3/Delivery.cfm/000324309.pdf?abstractid=218959\&mirid=1

6. Rezaee, Z. (2005). Causes, consequences, and deterrence of financial statement fraud. Critical Perspectives on Accounting, 16(3), 277-298.

7. Mulford, Ch. W., Comiskey, E. E. (2003). The Financial Numbers Game: detecting creative accounting practices. New York: John Wiley \& Sons.

8. Burgstahler, D., Eames, M. (2006). Management of Earnings and Analysts' Forecasts to Achieve Zero and Small Positive Earnings Surprises. Journal of Business Finance \& Accounting, 33(5-6), 633-652.

9. Podhorska, I., Siekelova, A., Olah, J. (2019). Earnings Analysis of SMEs: A Case Study in Slovakia. Proceedings of the 33rd International-Business-Information-ManagementAssociation (pp. 8706- 8718). Norristown: International Business Information Management Association - Ibima.

10. Svabova, L., Kramarova, K., Chutka, J., Strakova, L. (2020). Detecting earnings manipulation and fraudulent financial reporting in Slovakia. Oeconomia Copernicana, 11(3), 485-508.

11. Mulford, Ch. W. (2002). The financial number game: detecting creative account practices. New York: John Wiley \& Sons.

12. Kliestik, T., Valaskova, K., Lazaroiu, G., Kovacova, M., Vrbka, J. (2020). Remaining Financially Healthy and Competitive: The Role of Financial Predictors. Journal of Competitiveness, 12(1), 74-92.

13. Kovacova, M., Kliestik, T., Valaskova, K., Durana, P., Juhaszova, Z. (2019). Systematic review of variables applied in bankruptcy prediction models of Visegrad group countries. Oeconomia Copernicana, 10(4), 743-772.

14. Ionescu, L. (2019). Would Taxing the Robots Curtail Technological Advancement or Mitigate the Risks of Automation?. Contemporary Readings in Law and Social Justice, 11(1), 33-38.

15. Ullmann, R., Watrin, C. (2017). Detecting Target-Driven Earnings Management Based on the Distribution of Digits. Journal of Business Finance \& Accounting, 44(1-2), 63-93.

16. Hecht, B., Valaskova, K., Kral, P., Rowland, Z. (2019). The Digital Governance of Smart City Networks: Information Technology-driven Economy, Citizen-centered Big Data, and Sustainable Urban Development. Geopolitics, History, and International Relations, 11(1), $128-133$. 
17. Brazel, J. F., Jones, K. L., Zimbelman, M. F. (2009). Using Nonfinancial Measures to Assess Fraud Risk. Journal of Accounting Research, 47(5), 1135-1166.

18. Healy, P. (1985). The Effect of Bonues Schemes on Accounting Decisions. Journal of Accounting \& Economics, 7(1-3), 85-107.

19. DeAngelo, L. E. (1986). Accounting Numbers as Market Valuation Substitutes: A Study of Management Buyouts of Public Stockholders. The Accounting Review, 61(3), 400-420.

20. Beneish, M. D. (1997). Detecting GAAP Violation: Implications for Assessing Earnings Management among Firms with Extreme Financial Performance. Journal of Accounting and Policy, 16(3), 271-309.

21. Mantone, P. S. (2013). Using analytics to detect possible fraud: tools and techniques. Hoboken: Wiley \& Sons.

22. Kourilova, J., Drabkova, Z., Vlckova, M. (2016). Methods: AHP, CFEBT, DMFCA as a possible identification of errors and fraud in accounting. Ceske Budejovice: University of South Bohemia in Ceske Budejovice, Faculty of Economics.

23. Indiana University (2020). Beneish M-Score. Retrieved from: https://apps.kelley.iu.edu/Beneish/MScore/MScoreInput

24. Blazek, R., Durana, P., Valaskova, K. (2020). Creative accounting as an apparatus for reporting profits in agribusiness. Journal of Risk and Financial Management, 13(11), 261. 